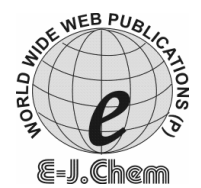

http://www.e-journals.net

ISSN: 0973-4945; CODEN ECJHAO

E-Journal of Chemistry

2009, 6(4), 1211-1220

\title{
A Novel Process to Prepare Chitosan Macrospheres without Shrinkage and its Application to Immobilize $\beta$-Galactosidase
}

\author{
SU-FANG SUN* and YAN ZHANG \\ College of Chemistry and Environmental Science, \\ Hebei University, Baoding 071002, P. R. China. \\ sunsufang@hbu.edu.cn
}

Received 12 November 2008; Accepted 15 January 2009

\begin{abstract}
A new process for the preparation of chitosan macrospheres, which was simple and practicable, was suggested in this paper and various chitosans with different molecular weight were used as materials to immobilize $\beta$-galactosidase and the chitosan macrospheres with the lowest molecular weight (500 000) was selected as enzyme immobilization carrier based on the highest enzyme activity. In order to overcome the shrinkage of chitosan during drying, the wet macrospheres obtained was treated by $30 \%$ glycerol solution for $1 \mathrm{~h}$ before drying and the results showed that the dried chitosan macrospheres obtained could keep almost the same structure as its wet form, which was very important for chitosan as enzyme carrier in industry. Finally, $\beta$-galactosidase from Aspergillus oryzae was immobilized on above dry chitosan macrospheres and a satisfactory result of the immobilized enzyme was obtained in enzyme activity yield, $\mathrm{pH}$ stability, thermal stability, operational stability, Michaelis constants $\mathrm{K}_{\mathrm{m}}$ and the maximum velocity $\left(V_{\mathrm{m}}\right)$.
\end{abstract}

Keywords: Chitosan macrospheres, $\beta$-Galactosidase, Glycerol, Immobilization,Glutaraldehyde

\section{Introduction}

Application of solid-phase biocatalysts had become important during the last decades. Enzymes could be immobilized on various supports and by different methods. The properties of the immobilized biocatalysts were influenced by the characteristics of enzyme, support material and the immobilization method. A suitable support should have high affinity to proteins, reactive functional groups, hydrophilicity, mechanical stability and rigidity. Chitosan was a natural polyaminosaccharide which offered the characteristics above; therefore it was often used for enzyme immobilization ${ }^{1,2}$. 
Chitosan macrospheres with size falling into millimeter range were often used to immobilize enzyme for practical purposes and it was often prepared by the precipitation method $^{3}$, the usual operation was to add flesh chitosan solution to a curing solution using a syringe by manpower, which waste a lot of time and manual labor. Except that, the macrospheres obtained shrunk greatly during drying because a lot of water was lost, thus the wet chitosan was often used and it was generally stored in aqueous solution, which would largely limit the industrial applications of chitosan. How to prevent its shrinkage during drying? No report was found to our knowledge except that the chitosan was coupled with other materials to form a complex product with a complicated reaction process ${ }^{4}$.

In this paper, a novel process, which would save a lot of time and manpower, was offered to prepare chitosan macrospheres and chitosan with different molecular weight was made into macrospheres to immobilize $\beta$-galactosidase, the one with the highest enzyme activity was chosen as the enzyme carrier. Besides, the strong and the flexible chitosan macrospheres without shrinkage during drying were obtained with glycerol solution as treatment agent and $\beta$-galactosidase from Asp. oryzae was employed to be immobilized on the above carrier with glutaraldehyde as crosslinker. Finally, the kinetic data of the immobilized enzyme, the values of Michaelis constants $K_{\mathrm{m}}$ and the maximum velocity $\left(V_{\mathrm{m}}\right)$ were also determined.

\section{Experimental}

$0.05 \mathrm{~g}$ of $\beta$-Galactosidase was weighed and extracted in $100 \mathrm{~mL} 0.1 \mathrm{M}$ sodium phosphate buffer ( $\mathrm{pH}$ 6.0), then the enzyme solution was obtained and stored in the refrigerator for use. The substrate solution was prepared by dissolving $0.0751 \mathrm{~g}$ ONPG in twice distilled water and made up $50 \mathrm{~mL}$ solution.

\section{Preparation of chitosan macrospheres}

$1 \mathrm{~g}$ of Chitosan with different molecular weight was accurately weighed and dissolved in acetic acid $(2 \%, \mathrm{w} / \mathrm{v})$ to form $5 \%$ solution (w/v). After the viscous solution obtained was placed in a vacuum dryer to remove air bubbles, it was placed into the syringe. After the water tap was opened, the air in the condenser was compressed, and the chitosan solution was extruded by the compressed air to spray drop-wise into a gently stirred coagulation liquid containing $15 \% \mathrm{NaOH}$ and ethanol in a volume ratio of $4: 1$ at a constant rate. The obtained macrospheres were filtered and washed with distilled water until neutrality. Then the macrospheres were divided into two groups, one group was stored in a refrigerator at $4{ }^{\circ} \mathrm{C}$ (support I) and the other was dried in the air (support II).

\section{The chitosan macrospheres treated with glycerol solution}

The obtained chitosan macrospheres were immersed in a 30\% aqueous glycerol solution for 1 hour. After the excess glycerol solution was removed, the obtained chitosan macrospheres were divided into two groups. One group was washed with distilled water for three times and stored in a refrigerator for use (support III) and the other was dried in a vacuum desiccator for $8 \mathrm{~h}$ at $85{ }^{\circ} \mathrm{C}$ and then stored at room temperature for use (support IV).

\section{Immobilization procedure}

Preparation of activated chitosan macrospheres by glutaraldehyde

$2 \mathrm{~g}$ of Chitosan macrospheres were washed and immersed in distilled water for $12 \mathrm{~h}$. After being dried with filter paper, the beads were placed in a $50 \mathrm{~mL}$ vessel containing $20 \mathrm{~mL}$ of $0.1 \%$ glutaraldehyde ( $\mathrm{pH} \mathrm{8.0)}$ and the reaction was carried out by shaking it for $2 \mathrm{~h}$ at $30^{\circ} \mathrm{C}$, then the 
activated macrospheres obtained were rinsed thoroughly and stored for the next use.

\section{Immobilization of $\beta$-galactosidase on activated chitosan macrospheres}

The immobilization was carried out by adding an amount of activated macrospheres $(0.1 \mathrm{~g})$ to $0.1 \mathrm{M}$ phosphate buffer ( $\mathrm{pH} 6.0)$ containing enzyme $(0.5 \mathrm{mg} / \mathrm{mL})$. With gently stirring, the reaction was allowed to proceed at $4{ }^{\circ} \mathrm{C}$, after $16 \mathrm{~h}$, the immobilized enzyme was filtered and washed with $0.1 \mathrm{M}$ phosphate buffer (pH 6.0) until no protein was detected.

\section{Enzyme activity assay}

The activity of the free and the immobilized enzyme was determined according to the references ${ }^{5,6}$ using ONPG as a substrate. For the free enzyme activity, aliquots of it $(0.1 \mathrm{~mL})$ were added to the mixture of $1.8 \mathrm{~mL} 0.1 \mathrm{M}$ phosphate buffer (pH 6.0) and $0.1 \mathrm{~mL}$ ONPG $(5 \mathrm{mM}$ ), after being incubated at $55{ }^{\circ} \mathrm{C}$ for $15 \mathrm{~min}$, the reaction of ONPG was stopped by the addition of $2 \mathrm{~mL} 1 \mathrm{~mol} / \mathrm{L} \mathrm{Na}_{2} \mathrm{CO}_{3}$ solution and the amount of ONP was measured directly at $405 \mathrm{~nm}$. For the immobilized enzyme activity, $0.5 \mathrm{~g}$ of the immobilized enzyme was soaked in $1.9 \mathrm{~mL} 0.1 \mathrm{M}$ phosphate buffer, the reaction was started by adding $0.1 \mathrm{~mL} \mathrm{ONPG}(5 \mathrm{~m} \mathrm{M})$. After being carried out for $15 \mathrm{~min}$ at $55^{\circ} \mathrm{C}$, the reaction was stopped and analyzed as above. The activity yield was calculated as the ratio of immobilized enzyme to enzyme subjected to immobilization. One unit of activity was defined as the amount of enzyme that liberated $1 \mu \mathrm{mol}$ of product/min at $55^{\circ} \mathrm{C}$.

\section{Influence of temperature and $\mathrm{pH}$}

The influence of temperature on the galactosidase activity was determined using ONPG as substrate over the range of 40 to $70{ }^{\circ} \mathrm{C}$. Enzyme stabilities were determined after a long duration exposure to various temperature $\left(50{ }^{\circ} \mathrm{C}, 60^{\circ} \mathrm{C}\right)$, followed by analysis at the $55^{\circ} \mathrm{C}$. The $\mathrm{pH}$ activity curve in the range 4.0-9.0 was determined for the free enzyme and the bound enzyme at $55{ }^{\circ} \mathrm{C}$ using ONPG as substrate. The $\mathrm{pH}$ stability in the range 3.0-11.0 was determined after $30 \mathrm{~min}$ exposure to different $\mathrm{pH}$ at room temperature.

\section{Kinetics}

The Michaelis constant $K_{\mathrm{m}}$ and the maximum velocity $V_{\mathrm{m}}$ were calculated for the soluble and the immobilized enzyme by assaying the enzyme in increasing ONPG concentrations ranging from $0.75 \mathrm{~m} \mathrm{M}$ to $7.5 \mathrm{~m} \mathrm{M}$ in phosphate buffer.

\section{Operational stability of immobilized enzyme}

The operational stability of the immobilized enzyme was determined according to the following procedures. 0.5 grams of the immobilized enzyme was taken and soaked in $1.9 \mathrm{~mL}$ phosphate buffer overnight, after the mixture was incubated at $55^{\circ} \mathrm{C}$ for $2 \mathrm{~min}$, the reaction was started by adding $5 \mathrm{~m} \mathrm{M}$ ONPG $(0.1 \mathrm{~mL}, \mathrm{pH} 6.0$, dissolved in the same buffer as described above) for $15 \mathrm{~min}$ at $55{ }^{\circ} \mathrm{C}$, and then the reactive mixture were analyzed. Afterward, the solid was filtered and washed thoroughly with distilled waster and the above experiment was repeated under the same conditions.

\section{Results and Discussion}

\section{Process to make chitosan macrospheres}

As we all know, macro-, micro- and nanosized chitosan particles were all suitable to immobilize enzyme, but for practical purposes, chitosan macrospheres were often used and it was often prepared by precipitation method. The operation was generally carried out by dropping the chitosan solution through a syringe into a gently stirred coagulation by 
manpower ${ }^{7}$, which was simple but waste a lot of time and manual labor. In our paper, an improvement of the precipitation method was carried out using compressed air instead of manpower, which was much faster and convenient than the traditional operation.

\section{Effect of various chitosan molecular weights}

Various chitosans $(500000,1000000,2000000)$ with nearly the same structure were used as materials to immobilize $\beta$-galactosidase, the results obtained were listed in Table 1 . From Table 1, it could be seen that activity and the recovery of the immobilized enzyme bound on the chitosan with 500000 molecular weight was the highest, which perhaps could be explained by the following facts: with the increase of the molecular weight, the chitosan molecular chain become long and the interaction of them was strengthened in the macrospheres, therefore the surface of the chitosan macrospheres become much closer, and the pores of the chitosan macrospheres were decreased or shrunk, which was not good to immobilize enzyme. So, it could be seen, when the chitosan was selected as enzyme immobilization carrier, the molecular weight of the chitosan was also very important in order to get the optimum immobilization effect. In our paper, the chitosan with 500000 molecular weight was selected in the later study.

Table 1. Effect of various chitosan molecular weights

\begin{tabular}{cccc}
\hline Chitosan & $\begin{array}{c}\text { Molecular } \\
\text { weight } \times 10^{4}\end{array}$ & $\begin{array}{c}\text { Immobilized enzyme } \\
\text { activity, U/g dry support }\end{array}$ & $\begin{array}{c}\text { Recovery of immobilized } \\
\text { enzyme, } \%\end{array}$ \\
\hline $\mathrm{C}_{1}$ & 50 & 71.43 & 60.35 \\
$\mathrm{C}_{2}$ & 100 & 66.19 & 55.55 \\
$\mathrm{C}_{3}$ & 200 & 62.33 & 52.02 \\
\hline
\end{tabular}

Effect of glycerol solution on chitosan macrospheres

It was found that the chitosan macrospheres shrunk greatly during drying (about from 2.2 $\mathrm{mm}$ to $0.9 \mathrm{~mm}$ ), and the diameter of the dry macrospheres was nearly fixed after being immersed in distilled water or buffer solution for enough time, which meant the structure of the chitosan macrospheres was destroyed during drying. Another experiment was also carried out to test above viewpoint; both wet and dry chitosan particles were taken and used to immobilize $\beta$-galactosidase under the same conditions, the enzyme activity of the latter was far lower than the former. Therefore, if dry chitosan macrospheres were needed, the wet ones must be treated further before drying.

In our experiments, glycerol solution was selected as treatment agent, and the effects of glycerol concentration and treatment time on the chitosan macrospheres were also investigated. Firstly, the treatment time of glycerol solution ranging from 0.5 to $2.0 \mathrm{~h}$ was discussed and the dry chitosan macrospheres treated by above solution were used to immobilize $\beta$-galactosidase, the results obtained were presented in Figure 1. From Figure 1, it could be seen that the enzyme activity of the immobilized enzyme increased firstly then decreased with the increase of treatment time and $1.0 \mathrm{~h}$ was found to be the best based on the highest enzyme activity. Then, various concentrations of glycerol solution from $10 \%$ to $60 \%$ were also examined, the dry carrier obtained was also used to bound enzyme under the same conditions (see Figure 2). Figure 2 shows that the activity of the immobilized enzyme was the highest when the glycerol concentration was $30 \%$, which might be explained by the following facts, the structure of the chitosan macrospheres could not be kept if the glycerol concentration was lower and the hole of the carrier could be blocked up if the concentration of the treatment solution was much higher. So $30 \%$ glycerol solution was selected in the next experiments. 


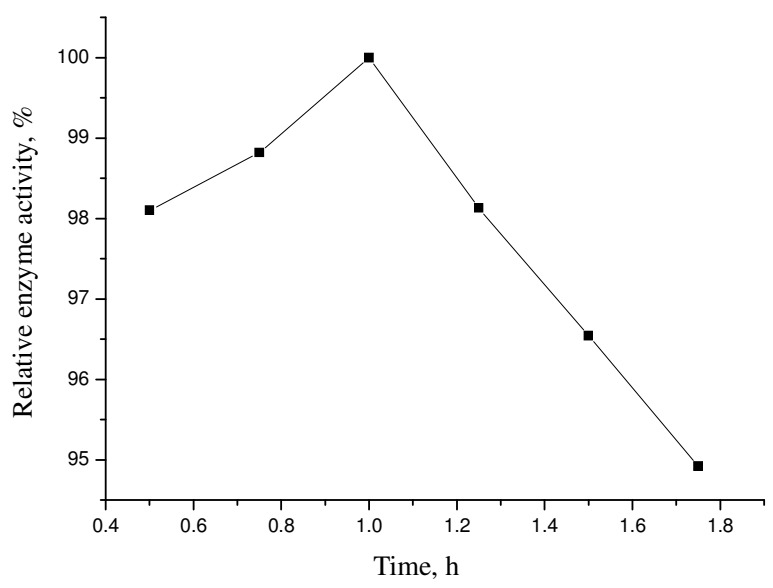

Figure 1. Effect of glycerol treatment time on the chitosan macrospheres.

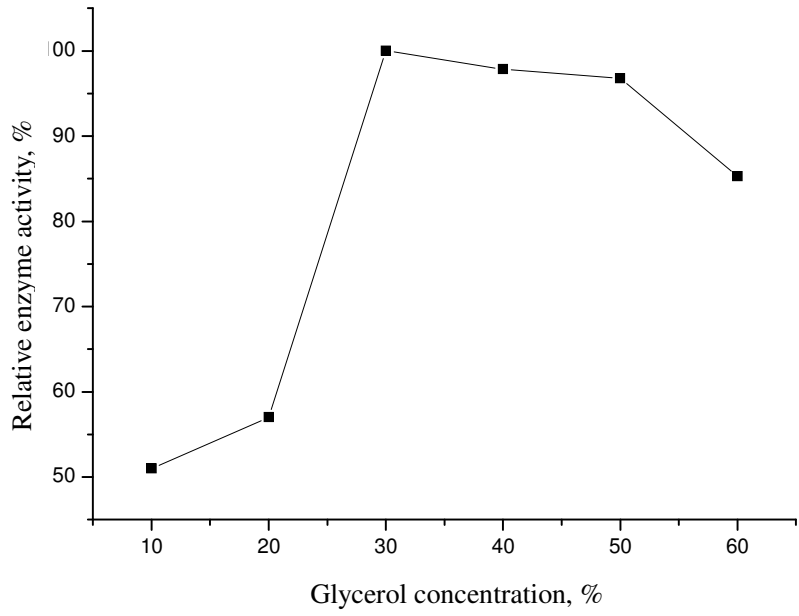

Figure 2. Effect of glycerol concentration on the chitosan macrospheres.

According to above optimum conditions, the chitosan macrospheres were treated by glycerol solution, and it was found that the diameter of the chitosan macrospheres with glycerol treatment kept nearly constant before and after drying at $85{ }^{\circ} \mathrm{C}$, but those without glycerol treatment shrunk greatly during drying at the room temperature. Meanwhile, SEM was done for both dry chitosan particles with and without glycerol treatment in order to understand the morphology of them, and the results obtained were shown in Figure 3 (a) (b). From the Figure 3 (a) (b), it could be seen that the surface of the carrier with glycerol treatment was loose and the apparent pores existed, but the carrier without glycerol treatment was close and nearly no pore was found. Meanwhile, four kinds of supports were taken and employed to immobilize enzyme, and the results obtained were listed in Table 2. From Table II, it could be seen that the enzyme activity of the wet macrospheres, the wet with glycerol treatment and the dried with glycerol treatment were almost the same, however, the enzyme activity of the dried support without glycerol treatment was just $10.29 \%$ of the wet support. 


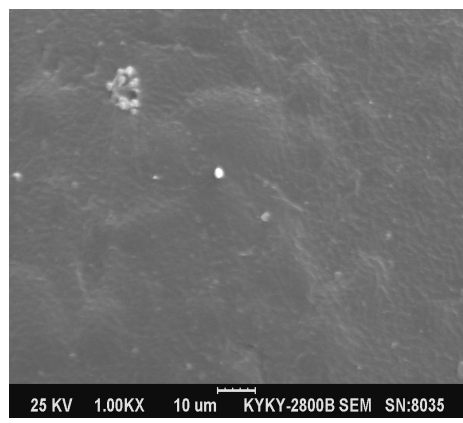

Figure 3 (a). Scanning electron micrographs of the supports II

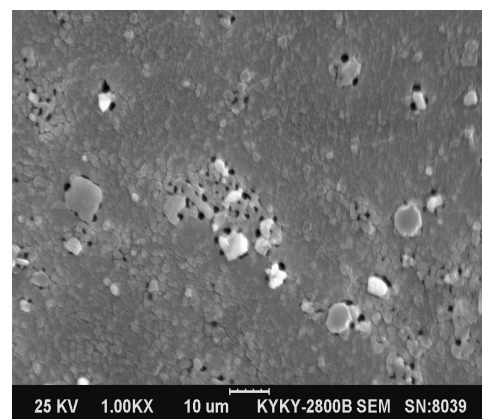

Figure 3 (b). Scanning electron micrographs of the supports IV

Table 2 Comparison of immobilized enzyme activity of different chitosan supports.

\begin{tabular}{lc}
\hline Type of supports & $\begin{array}{c}\text { Immobilized enzyme activity } \\
\text { (U/g dry support) }\end{array}$ \\
\hline I (the wet support) & 71.43 \\
II( the dried support without glycerol treatment) & 7.35 \\
III(the wet support with glycerol treatment) & 71.29 \\
IV(the dried support with glycerol treatment) & 69.61 \\
\hline
\end{tabular}

Based on above facts, we could see that chitosan macrospheres could be prevented shrinkage with glycerol treatment and kept nearly the same structure as its wet form. In the references reported using chitosan as immobilization carrier $^{8,9}$, wet macrospheres often employed in order to avoid its shrinkage during drying. It was not very good because the storage of wet form was inconvenient. Chitosan was also coupled with other inorganic materials ${ }^{10}$, which could prevent chitosan macrospheres from shrinking, but materials obtained were complex and the reaction process was usually very complicated. So the method developed here was very important for chitosan as enzyme immobilization carrier in industry.

\section{Properties of the immobilized enzyme}

\section{pH Optima and pH stability}

Figure 4 shows that the $\mathrm{pH}$ profile of the free enzyme peaked at $\mathrm{pH} 5.0$, while the immobilized enzyme peaked at $\mathrm{pH} 6.0$, a $\mathrm{pH}$ unit shift from the $\mathrm{pH}$ optimum for the soluble enzyme, which might be induced by the alteration of the microenvironment of the enzyme due to immobilization or support. Similar effects were also found for the immobilization of other enzymes on chitin and chitosan supports ${ }^{11}$. The enzyme activity was determined by ONPG as substrate, at $55^{\circ} \mathrm{C}$ in various $\mathrm{pH}$ buffers (4.0-9.0) for $15 \mathrm{~min}$.

After all the enzymes were exposed to different $\mathrm{pH}$ (3-11) at room temperature for 30 min, Enzyme activity was determined at $55^{\circ} \mathrm{C}, \mathrm{pH} 6.0$ for the immobilized enzyme and $\mathrm{pH}$ 5.0 for the free enzyme for $15 \mathrm{~min}$, ONPG as substrate. As shown in Figure 5, the immobilized enzyme had a wider $\mathrm{pH}$ range than that of the free enzyme, in the range of 3-10, the immobilized enzyme activity remained $>94.7 \%$.

Optimum temperature and thermostability.

Enzyme activity was determined by ONPG as substrate at various temperature $\left(40-70{ }^{\circ} \mathrm{C}\right)$ at pH 6.0 for 15 min. As seen in Figure 6, the immobilized enzyme temperature optimum was $55^{\circ} \mathrm{C}$, just like that of the free enzyme. 


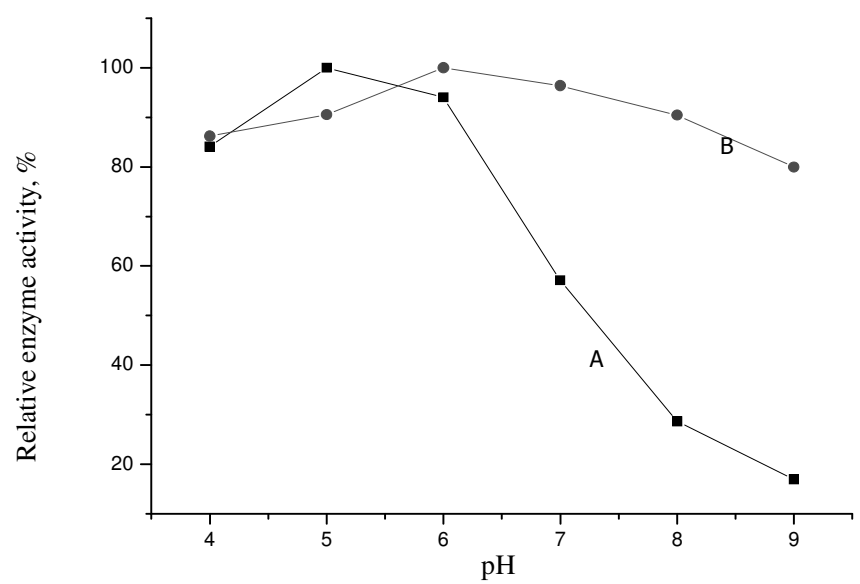

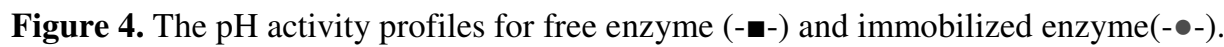

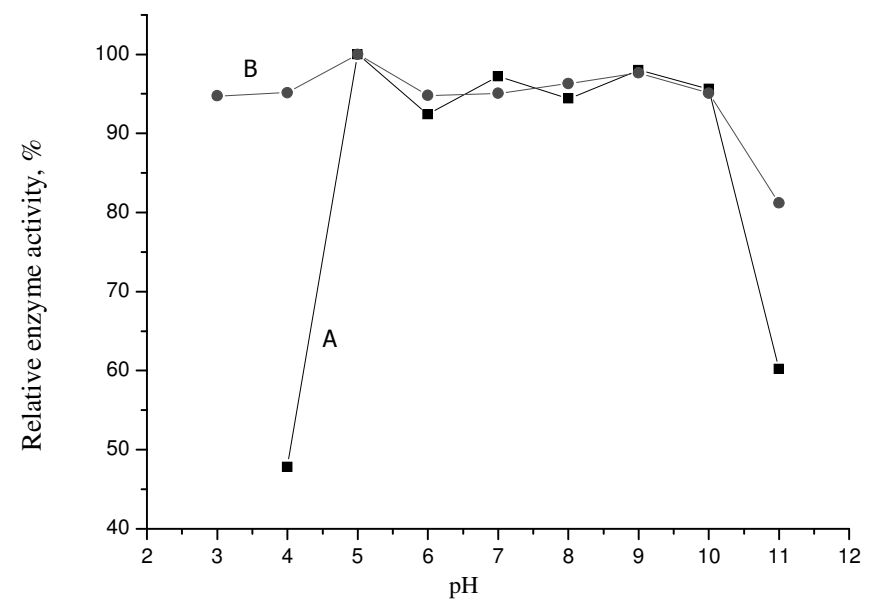

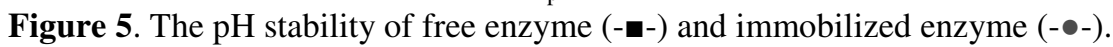

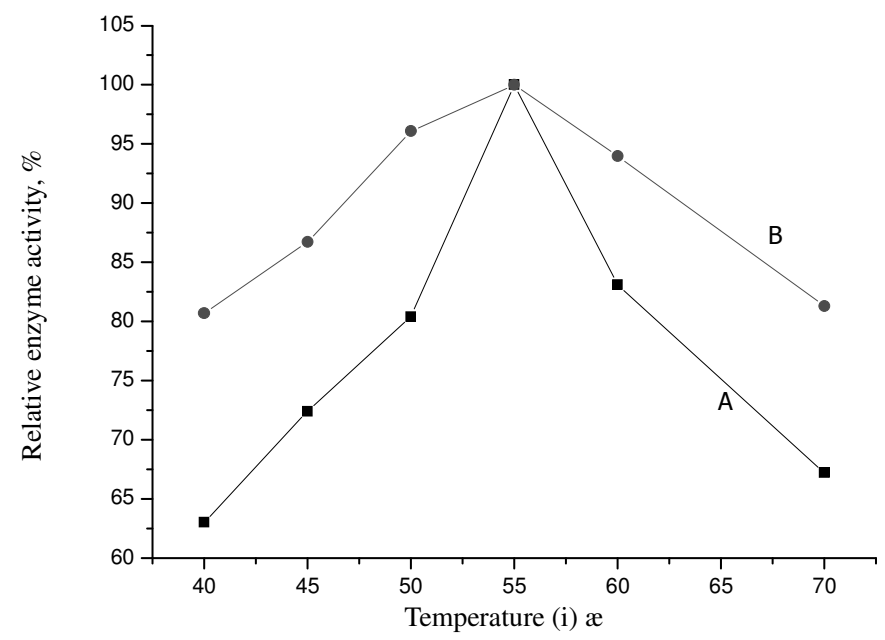

Figure 6. Temperature/activity profiles for free enzyme (-m-) and immobilized enzyme (-๑-). 
Figure 7 shows that the immobilized enzyme was more stable than the free enzyme. At $50{ }^{\circ} \mathrm{C}$, after $8 \mathrm{~h}$, the remaining activity of the former was $70.5 \%$, but the latter's was $47.8 \%$ (Figure 7a). At $60{ }^{\circ} \mathrm{C}$, over a period of the same time, the residual activity of the free enzyme was $40.9 \%$, whereas that of the bound enzyme was $54.8 \%$ (Figure $7 \mathrm{~b}$ ). Results showed that the immobilized enzyme had better thermostability than the free enzyme.

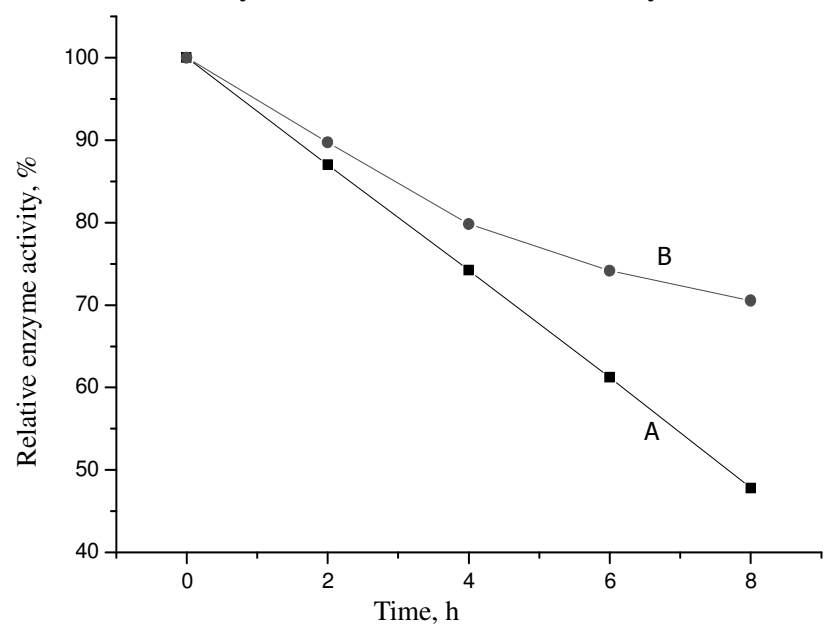

(a: $\left.50{ }^{\circ} \mathrm{C}\right)$

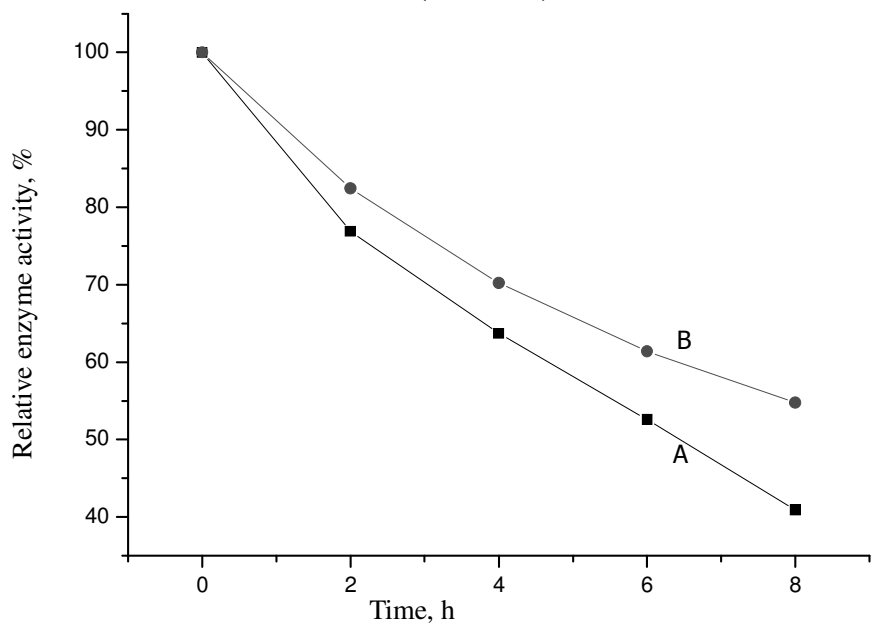

(b: $60^{\circ} \mathrm{C}$ )

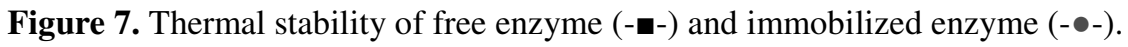

\section{Operational stability}

The experiment was repeated 10 times by using the procedures mentioned above with the same immobilized enzyme at the same initial concentration of ONPG. The results are summarized in Figure 8 and it was shown that the immobilized $\beta$-galactosidase was used for 10 times without significant loss in activity, meaning that almost no enzyme was dissociated from the surface of the chitosan in the course of the reaction, so the operational stability of the immobilized enzyme obtained was very good. 


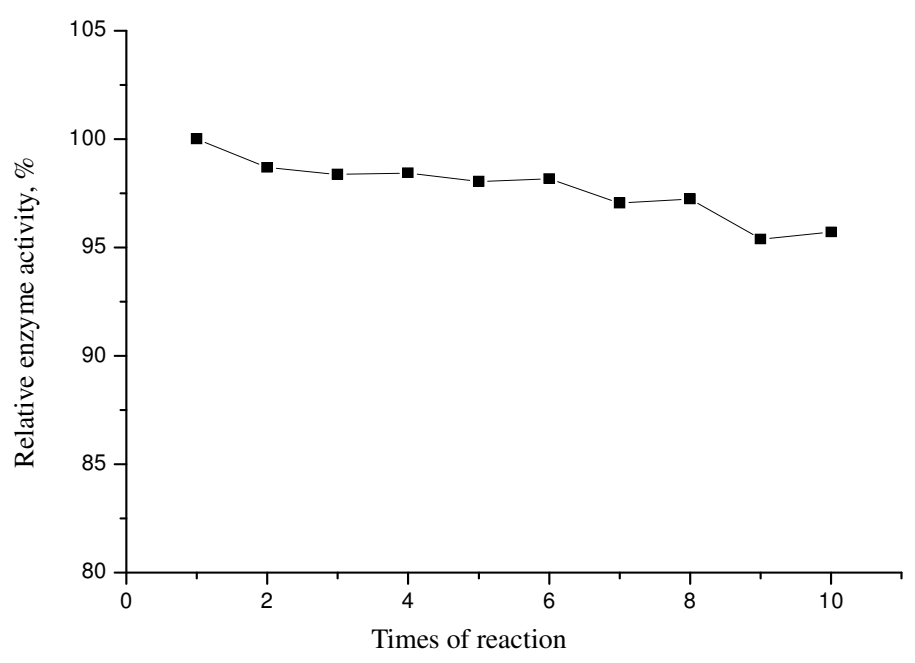

Figure 8. Operational stability of the immobilized enzyme

\section{Kinetic parameters.}

Lineweaver-Burk plot for the free and immobilized enzymes using ONPG as substrate was made and the values for $K_{\mathrm{m}}$ and $V_{\mathrm{m}}$ calculated from those graphs were shown in Table 3 . From Table 3, it could be seen that the value of $K_{\mathrm{m}}$ for the immobilized enzyme was approximately 2-fold higher than that of the free enzyme for the same substrate and the $V_{\mathrm{m}}$ value of the immobilized enzyme was about 1.5 times lower than that of the free enzyme, which was probably caused by the immobilization procedure and by the lower accessibility of the substrate to the active site of the immobilized enzyme ${ }^{12}$.

Table 3. Kinetic parameters of native and immobilized enzymes.

\begin{tabular}{ccc}
\hline Derivative & $K_{\mathrm{m}}, \mathrm{m} \mathrm{M}$ & $V_{\mathrm{m}}, \mu \mathrm{M} / \mathrm{min}$ \\
\hline Free enzyme & 10.2 & 0.278 \\
Immobilized enzyme & 18.8 & 0.183 \\
\hline
\end{tabular}

\section{Conclusion}

A new process to make chitosan macrospheres was offered in this paper, it was much more convenient and faster than the traditional operation, and various chitosan with different molecular weight was used as materials to immobilize $\beta$-galactosidase, the results showed that the molecular weight of the chitosan should be considered when we selected chitosan as enzyme immobilization carrier and the chitosan with the lowest molecular weight, i.e 500 000, was employed in our study based on the highest enzyme activity. More importantly, it was inconvenient for us to store the wet chitosan macrospheres in industry, but how to prevent it from shrinking during dying? A simple method was presented here, after being treated with $30 \%$ glycerol solution for $1 \mathrm{~h}$, the chitosan macrospheres could be dried nearly without shrinkage and kept almost the same structure as its wet form. Considering the inconvenience of the storage of the wet form, the dry chitosan macrospheres treated by glycerol solution were more applicable to immobilize enzyme. Finally, $\beta$-galactosidase from Aspergillus oryzae was immobilized on above dry chitosan macrospheres, properties of the 
free and the immobilized enzyme were compared, a satisfactory results of the immobilized enzyme were obtained in enzyme activity yield, $\mathrm{pH}$ stability, thermal stability and operational stability. In addition, $K_{\mathrm{m}}$ values for free and immobilized enzyme were 10.2 and $18.8 \mathrm{mM}$, respectively, and $V_{\mathrm{m}}$ values for them were 0.278 and $0.183 \mu \mathrm{M} / \mathrm{min}$ respectively. The conclusion obtained here was very useful for industrial application of chitosan macrospheres as enzyme immobilization carrier, and the procedure developed were simple, fast and inexpensive.

\section{Acknowledgement}

This work was supported by funds from the Natural Science Foundation of Hebei Province (No. B2007000146) and Plan Item of Hebei Province Science-Technology Department(No.06213014).

\section{References}

1. Abdullah J, Ahmad M, Karuppiah N, Heng L Y and Sidek H, Sensors and Actuators B: Chemical, 2006, 114, 604.

2. Gamze D A and Senay A C, Food Chem., 2007, 100, 964.

3. Chiu S H, Chung T W, Giridhar R and Wu W T, Food Res Int., 2004, 37, 217.

4. Xi F N and Wu J M, React Funct Polym., 2006, 66, 682.

5. Tu WX, Sun SF, Nu SL and Li XY, Food Chem., 1999, 64, 495.

6. Sun S F, Li X Y, Nu S L and You X, J Agric Food Chem., 1999, 47, 819.

7. Carrara C R and Rubiolo, Biotechnol Prog., 1994, 10, 220.

8. Biró E, Németh AS, Sisak C, Feczkó T and Gyenis J, J Biochem Biophy Methods, 2008, 70, 1240.

9. Shew D C, Li S Y, Duan K J and Chen C W, Biotechnol Tech.,1998, 12, 273.

10. Chang M Y and Juang R S, Biochem Eng J, 2007, 35, 93.

11. Bisset F and Sternberg D, Appl Environ Microbiol., 1978, 35, 750.

12. Muzzarelli R, Barontini G and Rocchetti R, Biotechnol Bioeng., 1976, 18, 1445. 


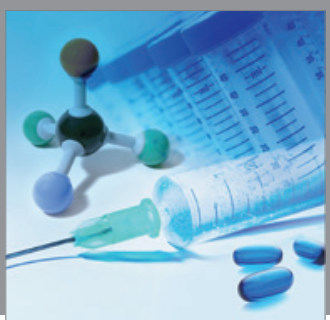

International Journal of

Medicinal Chemistry

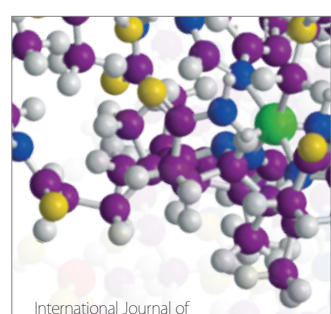

Carbohydrate Chemistry

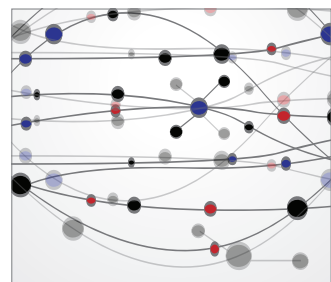

The Scientific World Journal
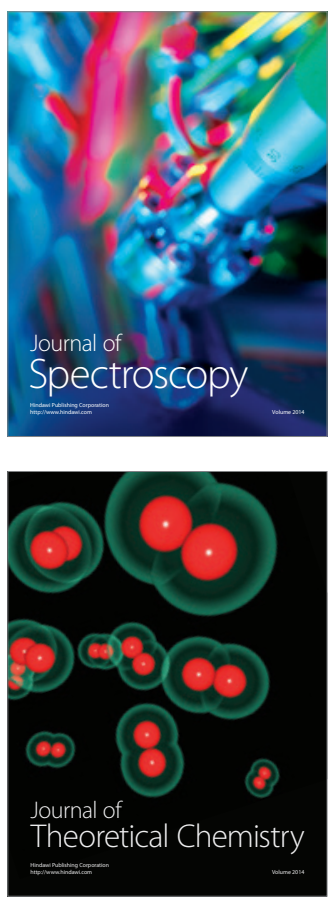
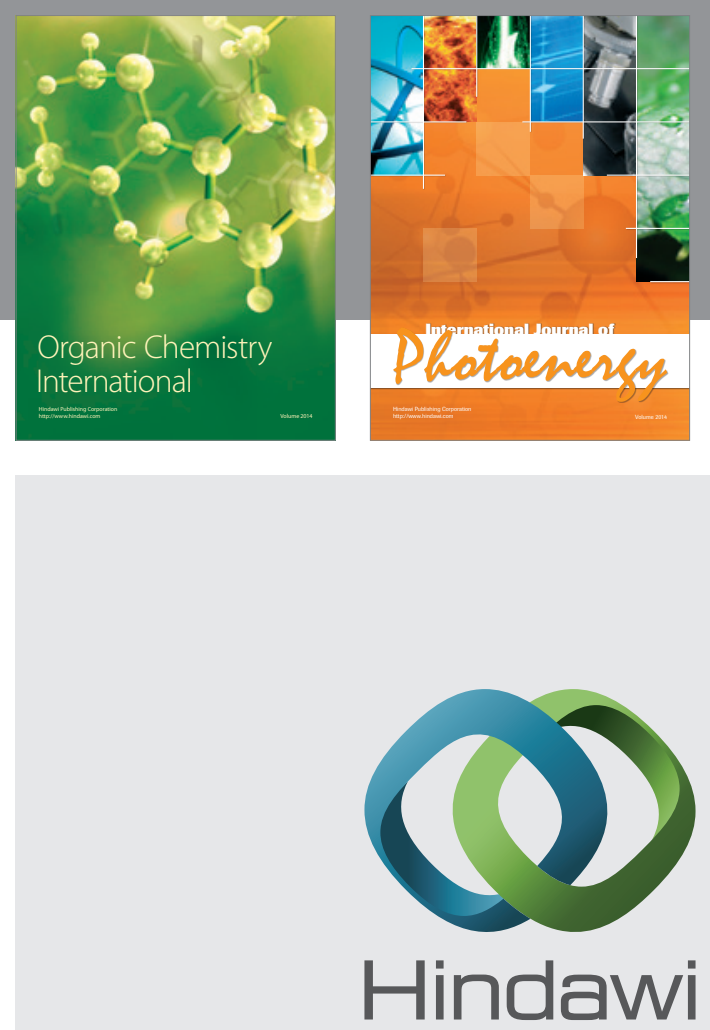

Submit your manuscripts at

http://www.hindawi.com
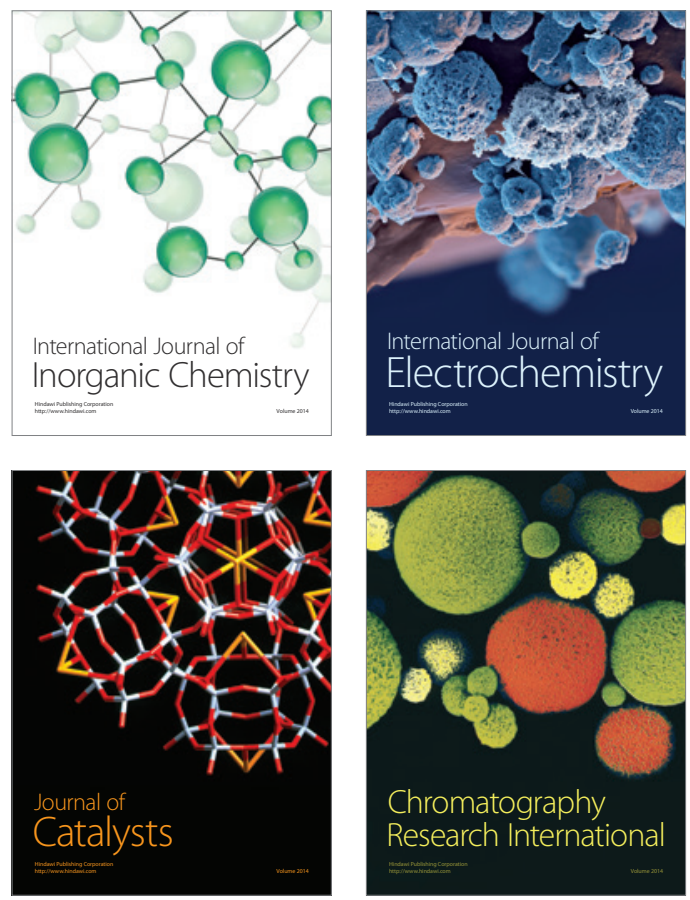
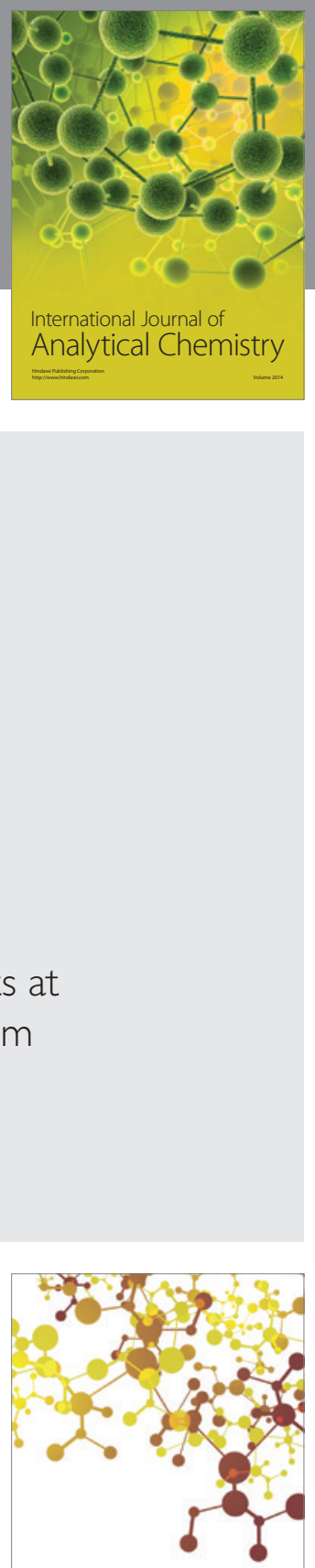

Journal of

Applied Chemistry
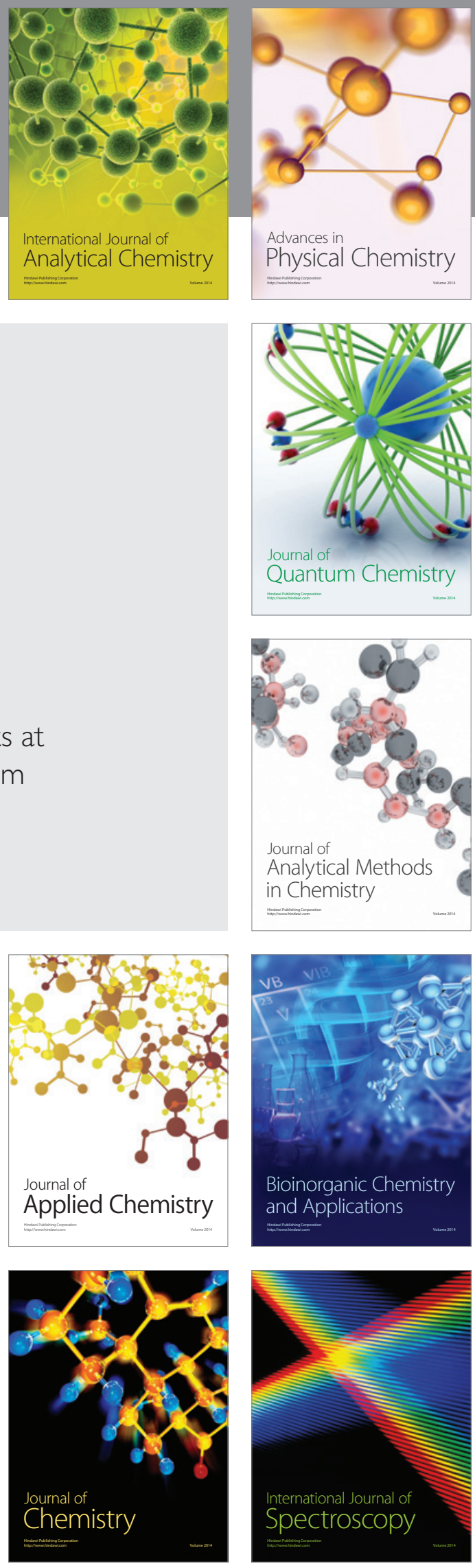